\title{
The Library of the Ethnographic Museum in Zagreb
}

\begin{abstract}
The Library of the Ethnographic Museum is a special museum library. It is of a semiclosed type, which is the case with most special and museum libraries. It is primarily intended for the museum staff: curators, conservators and preparators. It was founded not long after the museum had been established and it grew simultaneously with the museum collection. The paper provides an overview of its history, some of its more important collections and the processing of the publications. Nevertheless, it also presents some of the problems faced.
\end{abstract}

Key words: Ethnographic Museum (Zagreb)

museum library, museum editions, users

\section{INTRODUCTION: THE BEGINNING AND THE FOUNDATION OF THE LIBRARY COLLECTION: FROM A HANDY LIBRARY TO A SPECIAL AND SCIENTIFIC LIBRARY OF THE MUSEUM}

Soon after the foundation of the Ethnographic Museum, a handy library started being established. The expert museum staff employed at the time was scarce yet its members were aware that in order to become involved in serious work with museum objects they would require professional literature. Consequently, a handy library was established at the very beginning of the museum activity. It comprised of around two hundred publications (Gjetvaj 1898: 69). Nevertheless, only one year after that, in 1920, the library was established as a separate Museum Department.

The first books in the library were a gift from Salamon Berger, who at the time was the Director of the Museum, as well as those donated by the subsequent Director 
Vladimir Tkalčić. According to Tkalčić, during the first decade, the library collection increased to reach around one thousand and five hundred $(1,500)$ library publications (Tkalčić 1930: 143). In addition to the purchased, donated and exchanged publications, the library collection initially grew also due to own editions: "Narodna starina" was the joint publication of the Ethnographic Museum, the Zagreb City Museum and the Graphics Collection of the National and University Library in Zagreb. ${ }^{1}$ It was published from 1922 to 1935 and a total of thrity-five volumes were published in fourteen books.

"Zbirka jugoslavenskih ornamenata" (Collection of Yugoslav Ornaments) is a collection in six portfolios of a large format. Each portfolio comprises of several tables with illustrations of ornaments from textile and other objects with a brief description of individual illustrations. The portfolios were released during the period ranging from 1924 to 1939. The Collection had a huge circulation and it is even currently available in many antique shops.

In 1925, the Ethnographic Museum started with the publishing of the collection "Etnološka biblioteka" (Ethnological Library) in which the museum curators together with other authors published their papers linked with the museum work, museum collections and other ethnological topics. The Collection was published until 1934 and a total of twenty-one issues were published. A small booklet entitled "Walks through the Ethnographic Museum" by Mirko Kus-Nikolajev certainly needs to be highlighted among the first Museum editions. It was published in 1927 as a temporary guidebook through the first permanent exhibition staged at the Museum. At the time, the author was employed at the Museum as an Assistant.

In 1934, the Ethnographic Museum started publishing the journal "Ethnological Research and Material". Nevertheless, only four issues were published and the last one dates back to 1943. After a longer break, in 1981 the Museum continued publishing the journal entitled "Ethnological Research", which after its $7^{\text {th }}$ issue became an annual publication. In 2006, it started being published on "Hrčak", ${ }^{2}$ the central portal of the Croatian scientific and professional journals, with the "Ethnological Research No. 8" dating back to 2002 .

\section{EXCHANGE OF PUBLICATIONS WITH OTHER INSTITUTIONS AND LEGAL DEPOSIT COPIES}

In addition to a large number of museum editions of catalogues and other monograph publications, the library collection continued increasing also through the exchange of publications with other institutions that over time comprised of one hundred and eighty institutions from throughout the world and forty institutions in Croatia, including museums, institutes and libraries. Such exchanges contribute to a special value of the library, considering the fact that the institutions with which the first exchanges were performed included the Smithsonian Institution, the world's largest museum, education

1 Hereinafter NUL.

2 https://hrcak.srce.hr/etnoloska-istrazivanja (visited on $27^{\text {th }}$ March 2019). 
and research complex, which currently still sends us its valuable editions, significantly enriching the Museum Library.

It is also important to highlight a long-term continuous exchange with the British Museum - Royal Anthropological Institute ${ }^{3}$ and the Austrian Museum of Folk Life and Folk Art (Volkskundemuseum) in Vienna, as well as with the Museum of Ethnography (Néprajzi Múzeum) in Budapest. These are but a few of the most important museums in the world whose editions contribute to the value of the Library of the Ethnographic Museum. Considering the fact that the exchange is mutual, by definition, the museum library is enriched by the ethnographic publications from throughout the world, most of which, generally speaking, could not be purchased anywhere.

Our museum editions are also exchanged with and sent to all the major museums both throughout Croatia and the world, as well as to several institutes and libraries.

The first professional employee at the library - a librarian at the Ethnographic Museum and the author of this text, started working in 1995. Starting from that year, museum editions were sent as a legal deposit provisions to the largest library in the world, Library of Congress in Washington and the National and University Library (NUL) in Zagreb, which forwards the publications to other academic libraries in Croatia, as well as to the City Library for the local collection named Zagrabiensia. ${ }^{4}$ Hence, the Museum editions are available in all the major libraries both in Croatia and throughout the world.

\section{GIFTS AND PURCHASE OF PUBLICATIONS}

The library collection was enriched also by gifts and donations, as well as through purchase of all the relevant publications, to the extent that was made possible from the financial aspect. The publications primarily included resources in the field of ethnology, ethnography, cultural anthropology, museology/museum studies, culturology/cultural studies and other associated disciplines. The library collection increases in accordance with curator's work requirements and through efforts of the librarian, while striving to keep abreast with the contemporary relevant literature that this type of library needs to include.

\section{DONATIONS}

A huge proportion of the library publications has been donated, both as gifts from anonymous donors and gifts from our important ethnologists. Many publications reached the library from the journeys of the museum curators. Hence, the library holds several donations by its former employees, such as Jelka Radauš-Ribarić, Aleksandra-Sanja

\footnotetext{
3 British Museum, founded in 1753, was initially a library!

4 http://www.kgz.hr/hr/knjiznice/gradska-knjiznica-zbirka-zagrabiensia/o-zbirci-580/580 (visited on $1^{\text {st }}$ April 2019).
} 
Lazarević and Mario Petrić, to name a few. Many of the donated publications include authors' dedications, which additionally increase their value.

\section{RARE LIBRARY PUBLICATIONS}

The library holds around two hundred copies of rare publications. The latter include the publications dating back to the $18^{\text {th }}$ and the $19^{\text {th }}$ century, which is very rare and particularly valuable for the library collection. The rare publications also include the books deemed important for ethnography and ethnology, several ancient visual art portfolios, among which it is important to highlight primarily as follows: Carrara, Francesco. 1846. "La Dalmazia Descrita", Zara; as well as a valuable and rare graphic art of traditional folk costumes by Salvator, Ludwig. 1905. "Das was verschwindet: Trachten aus den Bergen and Inseln der Adria". Liepzig, Brockhaus and Friedrich Krauss and his "Anthropophyteia", published from 1904 to 1912, which provides an inexhaustible source of information about the sexuality of the peoples in the Balkans. Under the influence of Freud, Krauss, as a Viennese disciple, collected the wealth of erotic folklore, due to which he was even declared a pornographer. The Library of the Ethnographic Museum holds this entire valuable collection of ten books of enyclopaedic volume. At this point, it is also important to mention Alberto Fortis and his "Viaggio in Dalmazia", the original first edition dating back to 1774, which is also included in the museum library collection of rare publications.

A huge portfolio of work by Natalie Bruck-Auffenberg "Dalmatien und seine Volkskunst" is fundamental for the work of curators, primarily those involved in textile and traditional national costumes and its original edition dating back to 1911. The library collection also includes some old dictionaries such as the Dictionary (Gazophylacium) by Ivan Belostenec dating back to $1740^{5}$ and "Rječosložje ilirsko (slovinsko)-italianskolatinsko" by Joakim Stulli from $1806 .{ }^{6}$

Moreover, there are also several copies of rare religious books, both Catholic and Islamic.

Among rare book collection it is certainly important to highlight also ethnographic books, primarily German and Austrian editions dating back to the end of the $19^{\text {th }}$ and the beginning of the $20^{\text {th }}$ century that have a special value due to both their binding and printing.

Hence, around five hundred books need to be singled out, which need to be separately entered as cultural heritage. Unfortunately, under current conditions that task cannot be performed. It would require a substantial amount of time, each publication would need to be photographed (the covers, the front cover and several more important details) and cataloged in accordance with specific agreed upon rules. In that way, two or three publications may be cataloged per day, yet at the moment more importance is being attributed to the number of publications cataloged than to the processing of valuable

5 The bilingual Latin-Croatian Dictionary "Gazophylacium seu Latino-Illyricorum onomatum aerarium" (Gazophylacium: Latin-Croatian Dictionary).

6 Illyrian-Italian-Latin Dictionary (1806). 
publications. In fact, also in library profession the quantity of work is frequently given precedence over quality.

\section{ORGANISATION OF THE COLLECTION}

As has previously been pointed out, museum library collection is currently collected and processed in the same manner as in other special libraries in compliance with the standards and rules of the library profession. Nevertheless, from the foundation of the museum library to 1993 the publications were processed in accordance with Prussian rules. $^{7}$ There was an alphabetical and a field catalogue, which is still used. The field catalogue was simultaneously also the location catalogue since in the library the publications are arranged according to professions - fields of science. All the publications were initially under the call number/shelfmark E - ethnology. Following the increase in the library collection, the collections were divided into some twenty professional fields, some of which amounted to only a few volumes and some collections such as $\mathrm{Ka}$ - catalogues, Et -Ethnography and Mu - Museology or Museum Studies reached several thousands of volumes. The professional field marked with $\mathrm{Tx}$ - textile has been continuously expanding. Textile and clothing have always been the initial, the principal and the most numerous objects at the museum, which is the case also in most other ethnographic museums. The letter E still denotes Non-European Ethnology and it has already exceeded a thousand units of publications. Moreover, there are professions: History of Art, History, Archaeology, Cultural History and professions with a smaller amount of publications: Economics, Technology and Pedagogy, to name a few. It is important to point out $\mathrm{O}$-Orientalistics as a separate profession, which includes valuable ancient publications primarily linked with India, yet newer publications are included in the collection under E - Non-European Cultures, where they actually belong.

The library collection under the shelfmark $\mathrm{Pr}$ - Manuals is a separate section and it comprises of general works, encyclopedias and bibliographies. Publications under $\mathrm{R}$ - Dictionaries are also separated. The interest in the purchase of the last two groups is gradually decreasing since all the information of this type is currently available on the Internet: the Miroslav Krleža Institute of Lexicography has uploaded most of its editions on the Internet and hence the library, which is already crammed with books, is no longer in search for these primarily massive publications, in which the provided information is subject to frequent changes.

\section{PERIODICALS}

The curators who used to work at the library considered periodicals as a challenge and hence the periodicals comprise of two rows of call numbers/shelfmarks $\check{C}$ - Journals and $\mathrm{Z}$ - Miscellanies which are also journals, but they were referred to as Miscellanies and were hence marked with Z, although they should all be marked with Č - Journals.

7 http://dzs.ffzg.unizg.hr/text/pog4.htm (visited on 23 ${ }^{\text {th }}$ August 2019). 
Nevertheless, these call numbers/shelfmarks have not been altered and all the publications have been included under journals and can easily be found.

It is important to mention as a curiosity that upon the first revision of the journals I came across the Rusian journal entitled Entomology, which had apparently not been identified as one that does not belong to the collection at all. The journals on the shelves have been divided into two rows, where one row includes national journals and the other international journals.

The Library of the Ethnographic Museum comprises of almost all the older ethnographic journals from the territory of the former Yugoslavia, such as Herald of the National Museum, the oldest journal from the largest museum and one of the oldest libraries in the former Yugoslavia located at the National Museum of Bosnia and Herzegovina in Sarajevo $^{8}$ that was severely damaged during the war waged between 1992 and $1995 .{ }^{9}$

It has to be highlighted that the library includes the five volumes of the Croatian Encyclopedia published from 1941 to 1945. The fifth volume is rare and almost its entire circulation was destroyed in $1945 .{ }^{10}$ This encyclopedia is a particularly valuable source of information for Ethnology, as at the time the most distinguished scientists and experts were involved in its creation. ${ }^{11}$

In addition to all the ethnographic periodicals in the former Yugoslavia, the Library of the Ethnographic Museum holds all the contemporary ethnographic editions on the territory both of Croatia and former Yugoslavia. Moreover, there is a large number of international journals, among which it is important to mention the German "Zeitschrift für Ethnologie" and the British "Man: the Journal of the Royal Anthropological Institute", by the British Museum. It has to be highlighted that a huge influx of Germanic journals was evident during the period preceding the World War Two, between 1930 and 1945, primarily German, Austrian and Swiss, but that topic needs to be tackled separately in another paper. Even currently, the Vienna-based Ethnology Museum regularly sends all its editions within the exchange programme, although our Museum is currently not able to participate in the book exchange to the same extent since the number of its editions on an annualised level is considerably smaller. ${ }^{12}$

8 https://www.zemaljskimuzej.ba/bs/biblioteka (visited on $28^{\text {th }}$ March 2019).

9 The Museum Director at the time, Rizo Sijarić was killed during that period. Even after the war the Museum faced an extremely difficult situation. On the $4^{\text {th }}$ October 2012, after 124 years of activity, the Museum closed amid bickering over financing. The Museum opened again only on the $15^{\text {th }}$ September 2015 . At this point, I have to point out that the US wanted to exploit the difficult financial situation and a huge amount of money was offered for the purchase of the most valuable edition held by the Library of the National Museum, the reputable Sarajevo Haggadah. Nevertheless, curators and librarians did not accept their offer although at the time they were not receiving any salary and they were working without heating in dire conditions. The only thing that I can say is Good job, colleagues!

https://en.wikipedia.org/wiki/Sarajevo_Haggadah (visited on 23 ${ }^{\text {th }}$ May 2019). https://www.tportal.hr/kultura/ clanak/metropolitan-muzej-zeli-izloziti-sarajevsku-hagadu-20121204 (visited on 14 ${ }^{\text {th }}$ August 2019).

10 https://hr.wikipedia.org/wiki/Hrvatska_enciklopedija_(Ujevi\%C4\%87) (visited on 22 $2^{\text {th }}$ August 2019).

11 The Institute of Lexicography yet again launched a new edition of the Croatian Encyclopedia, from 1999 to 2009. It has been digitised since 2013 and available on the website of the Miroslav Krleža Institute of Lexicography.

12 Before the Internet was invented, the Vienna Volkskunde Museum also used to send its exhibition posters, kindly asking us to place them in a visible position by the entrance, which we did. 
The Museum also participates in a long-term and regular exchange with the Hungarian Ethnographic Museum / Néprajzi Múzeum. It still retains the spirit of the AustroHungarian Empire in the positive sense. Unfortunately, these Hungarian publications are primarily in the Hungarian language and hence they are not so useful for our curators, although this museum stages some very interesting and high quality exhibitions.

\section{LIBRARY COMPUTERISATION}

Starting from 1993 the library became involved in the processing of publications under CROLIST library management system. The system was developed by a group of computer science experts from the National and University Library in Zagreb and it was generously provided to 300 libraries throughout Croatia to be used free of charge. Nevertheless, over time, the system was abandoned and the National and University Library provided a new one, this time at a fee and it was not affordable for most of the previously mentioned 300 libraries. Hence, many libraries were faced with a humiliating situation. Museum libraries with scarce funding for whom there was no adequate substitutional system were in the worst position. There is a magnificent library management system Koha, ${ }^{13}$ free of charge, developed in 1999 in Great Britain, yet in order to implement and maintain it, institutions need to hire an IT specialist and unfortunately the Ethnographic Museum does not employ one. Within a limited range of available software solutions, none of which is fully adequate for museum libraries, the Ethnographic Museum has opted for Zaki library management system: developed in accordance with the standards of library cataloging of publications. It is financially accessible and there is a possibility for continuous assistance provided by both an IT specialist and a librarian during work. The system was developed through co-operation of Zagreb City Libraries and the company Viva-info. Nevertheless, over time, the software proved more effective for public libraries, rather than for special museum libraries, yet it still functions satisfactorily because it is user-friendly. Unfortunately, during the transfer from CROLIST into Zaki performed in 2013, a considerable amount of records was lost for unexplained reasons and hence the only available option was to once again catalog all the previously processed publications.

Museum Library collection catalogued through Zaki has been available online to all the users since October 2015. The advantage of Zaki software is that it is very easily accessed by the users because it enables simple search even for non-professionals in accordance with different searching techniques. ${ }^{14}$

I believe it is also important to mention that through the librarian and thanks to the offer made by the National and University Library, the digitised publications have been included in the DOI ${ }^{15}$ system since 2018. DOI identifier will from now on be assigned to digitised scientific and professional publications of the Ethnographic Museum through

13 http://www.koha.org/ (visited on $28^{\text {th }}$ March 2019).

14 http://kem.zaki.com.hr/ (visited on $28^{\text {th }}$ March 2019).

15 http://www.nsk.hr/doi/ (visited on $29^{\text {th }}$ March 2019). 
which the Museum keeps abreast with new systems in publishing industry and library science that are intended for digital identification of all types of publications.

\section{CONTENT PROCESSING OF THE PUBLICATIONS AND THE THESAURUS OF THE ETHNOGRAPHIC OBJECTS AT THE MUSEUM}

Until 1993, content processing of the publications was performed in accordance with the shelfmarks that followed the library classification. Starting from 1993, content processing of the publications has been performed in accordance with the UDC classification of books and keywords (Kolbas 1998), although the formerly used classification by shelfmarks has still been retained because of the location of the publications. The option of labelling objects within Zaki is very complicated and inadequate for an ethnographic library and it is hence rarely used, with the exception of publication for which records are taken over, even though these records are not always adequate. However, it is impossible to change them. Key words are a very simple processing method, they are accessible to the users for easy search and are hence used for content processing because the users very frequently do not have the references, but thematic questions. UDC system provides a rather outdated classification for ethnology, but it is still useful for search of publications as it can be adapted to meet the requirements of every specific library.

The Ethnographic Museum has had a need for a thesaurus for a long time. ${ }^{16}$ Many other scientific disciplines have thesauruses, while Ethnology and Cultural Anthropology still do not. Ethnography abounds with names that do not have equivalents in standard language and many museum objects have a large number of names ${ }^{17}$ that need to be systematically entered into a thesaurus. The Head of the Library at the Ethnographic Museum is an Ethnologist and holds a M.Sc degree in Linguistics, with a ten-year experience in work on a thesaurus at the National and University Library and on the science project for the Institute of the Croatian Language and Linguistics for an actual thesaurus. ${ }^{18}$ Consequently, in 2006, work started on a thesaurus of ethnographic museum objects with the colleague Ethnologist, Aleksandra Vlatković, encouraged by Ivan Šestan, who at the time was a Museum Registrar at the Ethnographic Museum. Most of the Thesaurus had been completed for the class dedicated to Economy, ${ }^{19}$ nev-

16 "Thesaurus is a controlled vocabulary for indexing, organised in the manner that makes it possible to clearly present the relationships between concepts in order to be used for searching. Thesaurus is organised knowledge in accordance with what is both offered and enabled by computers and the Internet" (Kolbas, unpublished lecture from a symposium, 2016).

"Thesauruses (are) structured lists of concepts that change simultaneously with the development of science and human actions and from which specific concepts "appear" outdated, while new and more relevant ones are being included" (Kolbas 2006: 97).

17 http://www.klubputnika.org/zbirka/putoskop/3822-seflja-paljak-kaciol-grabljaca-kutlaca-ili-pak-zaimaca (visited on $26^{\text {th }}$ March 2019).

18 http://zprojekti.mzos.hr/public/c2prikaz_det.asp?cid=2\&psid=32\&ID = 3482 (visited on 23 ${ }^{\text {th }}$ March 2019).

19 More information provided in the paper entitled "A Report on the Work on the Thesaurus of Ethnographic Museum Objects for 2008" by the authors I. Kolbas and A. Vlatković (2009). 
ertheless after several years of work the interest in the project in the parent company faded. It will have to continue sometime because any serious discipline needs to have its Thesaurus. A unified and systematically arranged terminology - a thesaurus - is imperative for comprehensive work on both library and museum items. ${ }^{20}$

\section{WORK WITH THE USERS}

Over the last twenty-odd years, the library is faced with the issue of shortage both of work space and storage space for the publications. The space in which external users of the library could work is almost non-existent. Inside $41 \mathrm{~m}^{2}$ of library space in which there are currently almost 30,000 publications, it is no longer possible to make room for all the newly arrived publications. Consequently, some publications are held in boxes, which is certainly not acceptable and hence the library looks more like a storage than a library. The Museum façade is currently being renovated and the adaptation of the museum premises is being planned. Nevertheless, around $40 \mathrm{~m}^{2}$ of additional space is planned for the library, which is still insufficient. In accordance with the proposal included in the "Standard for Special Libraries in the Republic of Croatia", adopted in September 2011, a special library with a collection comparable to the collection of the library at the Ethnographic Museum requires around $200 \mathrm{~m}^{2}$ of space in which it is possible to adequately arrange the publications, where the librarian is allocated some work space and which also provides work space for at least 4 users and certainly also computers at which they could work. ${ }^{21}$

It is important to point out that, although the library is intended primarily for museum expert staff, it is available also for external users who can also use the publications, which includes colleagues' ethnologists and other scientists, as well as students. The librarian is also available to provide any required information to the wider public concerning the library collection and ethnographic/ ethnologic, cultural - anthropological and folklore publications.

\section{LIBRARY STAFF}

As previously mentioned, many curators have worked at the library since the foundation of the Ethnographic Museum. It was additional work for them and they did it besides the management of the museum collections they were in charge of. Starting from 1995, the Museum hired the author of this text as the first librarian at the Library of the Ethnographic Museum. The first revision of the collection was performed during the period between 2001 and 2002. In accordance with the standards of the profession,

202016 saw the launch of a pan-European project for arts and humanities named DARIAH for which the author of this text held a lecture about the work of the thesaurus http://has.dariah.eu/?p=494 (visited on $23^{\text {th }}$ May 2019).

21 Find out more at: https://www.google.com/url?sa = t\&rct =j\&q = \&esrc $=$ s\&source $=$ web\&cd $=2 \&$ ved $=2$ ahUKEw jqz77R64HkAhVCzKQKHY4KDBwQFjABegQIAxAC\&url = https\%3A\%2F\%2Fwww.hkdrustvo.hr\%2Fclanovi\%2Falib\%2Fdatoteke\%2Ffile\%2FStandardi\%2FSTANDARDI\%2520ZA\%2520SPECIJALNE\%2520KNJI\%25C5\%25BDNICE1. doc\&usg $=$ AOvVaw0uSuSf2r8ILFMZWUUTNxKL (visited on $20^{\text {th }}$ August 2019). 
the revision must not be performed only by one librarian and hence the author of this text performed it with a trainee.

In the future, the employment of at least two librarians at the library needs to be envisaged. One of them would be in charge primarily of the processing of library publications and the other one would be doing the remaining work. That would make it possible to do work on bibliographies, as well as on lists of provided publications that would be available also on the museum website. Moreover, it would be possible to perform the previously mentioned processing of the particularly valuable publications that need to be registered as cultural heritage, in accordance with the previously established rules with the librarians from other museum libraries, as well as to do other work and activities that a museum librarian is expected to do and be involved in.

\section{INSTEAD OF A CONCLUSION: ARE MUSEUM LIBRARIES NECESSARY?}

The importance of museum libraries is shown by the information that libraries were founded simultaneously with the foundation of museums, as a fundamental segment of professional and scientific work at the museum. The end of the $19^{\text {th }}$ century saw the establishment of a large number of museums and simultaneously also the foundation of library science, as a discipline and a study programme. ${ }^{22}$ At the time, the museums frequently employed museum directors and other scientific and expert staff at the library and that was also the case at the Ethnographic Museum. Moreover, the first donors to the museum library and the first museum directors were from the Ethnographic Museum: Salamon Berger, as the first Museum Director and Vladimir Tkalčić, as the first curator and subsequently also the Director. Antun Bauer, a distinguished Croatian museum professional, a Museologist and the founder of Museum Documentation Centre, pointed out the importance of museum libraries. It took a long time to hire a librarian at the Ethnographic Museum, as it occurred only in 1995. Nevertheless, before that individual curators were in charge of the library, which they did very successfully, besides doing their main job, that of a curator.

Unfortunately, museum libraries do not generate profit and the value of the knowledge stored in the library is priceless, due to which libraries are not considered cost-effective in accordance with the criteria adopted among the financiers. Consequently, during the last several years, the Library of the Ethnographic Museum has been provided with rather scarce financial resources to be used for its work. It is important to highlight that in the 2000's, the library used to be allocated from HRK 40,000 to HRK 50,000, as opposed to the last several years in which it has been allocated from HRK 10,000 to HRK 15,000. During the last several years, the library of the Ethnographic Museum and most other museum libraries are no longer financed by the Ministy of Culture of the Republic of Croatia, but only by the City Office for Culture of the City of Zagreb.

22 http://www.enciklopedija.hr/natuknica.aspx?id = 7465 (visited on 23 ${ }^{\text {th }}$ August 2019). 
While IFLA (International Federation of Library Associations and Institutions) as the leading international body representing the interests of libraries recognises the value of museum libraries from which it requests the registration of a proportion of their funds as cultural heritage, while simultaneously I need to reiterate that the Ministry of Culture of the Republic of Croatia has not financed the work of the museum libraries for the last several years. According to the information from Library Statistics of the National and University Library (NUL) for 2018, the share of the resources allocated to the Library in the overall resources allocated to the Museum reached only $2.5 \%{ }^{23}$ Nevertheles, there are museums that are allocated even less funding, which is not conforting, but alarming in terms of the future of museum libraries. At this point, I need to reiterate yet again the inadequacy of the space allocated to the Library at the Ethnographic Museum, because it needs to be at least four times larger. Nevertheless, it appears that in the new Museum facilities a similar inadequate space has yet again been envisaged, through which the size of the library will increase by less than one fourth of the required space.

In accordance with the contemporary requirements faced by the museum profession, such as a greater involvement of the community in museum operations, the special museum library also needs to be considered as an extremely important segment in potential connecting with the users - as a venue in which external users, members of the community with which the museum is closely co-operating, will be spending time, exploring and studying. Consequently, adequate premises need to be provided for such future use. An excellent example of the latter is the library of the Slovene Ethnographic Museum in Ljubljana, whose size is almost identical to that of the Library of the Ethnographic Museum in Zagreb. ${ }^{24}$

As previously stated, the future of museum libraries in Croatia is not promising and it is possible that some of them will even close. I hope that the latter will be disproved over the time, since museum libraries hold valuable books that cannot be found in other libraries and need to be registered as cultural heritage, in addition to the fact that museum libraries, as other special libraries, are imperative for professional and scientific work of the employees in the institutions in which they operate.

\section{REFERENCES:}

GJETVAJ, Nada. 1989. “Etnografski muzej u Zagrebu - u povodu 70. obljetnice”. Etnološka istraživanja 5 .

KOLBAS, Irena. 1998. "Sadržajna obrada građe u knjižnici Etnografskog muzeja". Informatica museologica 29: 21-23.

KOLBAS, Irena. 2006. “Tezaurus etnologije ali kulturne antropologije”. Etnološka istraživanja 11: 95-109.

23 Information from Library Statistics by the National and University Library (NUL) for 2018, hk.nsk.hr (visited on $27^{\text {th }}$ March 2019).

24 https://www.etno-muzej.si/sl/lokacije/knjiznica (visited on $26^{\text {th }}$ August 2019). 
KOLBAS, Irena i Aleksandra VLATKOVIĆ. 2009. "Izvještaj o radu na Tezaurusu etnografskih muzejskih predmeta za 2008. godinu”. Etnološka istraživanja 11: 387-389.

KOLBAS, Irena. 2011. “Razmjena knjižnične građe Etnografskog muzeja u Zagrebu”. Etnološka istraživanja 16: 265-267.

TKALČIĆ, Vladimir. 1930. “Etnografski muzej u Zagrebu 1919-1929.”. Narodna starina 9: 132-148.

http://zprojekti.mzos.hr/public/c2prikaz_det.asp?cid=2\&psid=32\&ID =3482 (visited on $23^{\text {th }}$ March 2019).

https://www.google.com/url?sa $=\mathrm{t} \& \mathrm{rct}=\mathrm{j} \& \mathrm{q}=\& \mathrm{esrc}=\mathrm{s} \&$ source $=$ web\&cd $=14 \& \mathrm{ved}=2 \mathrm{ahUKE}$ wiBpoTk053hAhWG16QKHajsAK0QFjANegQIAhAC\&url=https\%3A\%2F\%2Fhrcak.srce.hr \%2Ffile\%2F98941\&usg =AOvVaw2vtnQ6D5cXxII2HOXiyEtX (visited on $25^{\text {th }}$ March 2019).

http://www.klubputnika.org/zbirka/putoskop/3822-seflja-paljak-kaciol-grabljaca-kutlacaili-pak-zaimaca (visited on $26^{\text {th }}$ March 2019).

https://hrcak.srce.hr/etnoloska-istrazivanja (visited on $27^{\text {th }}$ March 2019).

http://kem.zaki.com.hr/ (visited on $28^{\text {th }}$ March 2019).

http://www.koha.org/ (visited on 28 ${ }^{\text {th }}$ March 2019).

https://www.zemaljskimuzej.ba/bs/biblioteka (visited on $28^{\text {th }}$ March 2019).

http://www.nsk.hr/doi/ (visited on 29 ${ }^{\text {th }}$ March 2019).

http://www.kgz.hr/hr/knjiznice/gradska-knjiznica-zbirka-zagrabiensia/o-zbirci-580/580 (visited on $1^{\text {st }}$ April 2019).

http://has.dariah.eu/?p=494 (visited on $23^{\text {th }}$ May 2019).

https://en.wikipedia.org/wiki/Sarajevo_Haggadah (visited on $23^{\text {th }}$ May 2019).

https://www.tportal.hr/kultura/clanak/metropolitan-muzej-zeli-izloziti-sarajevskuhagadu-20121204 (visited on $14^{\text {th }}$ August 2019).

http://www.enciklopedija.hr/natuknica.aspx?id=7465 (visited on $23^{\text {th }}$ August 2019).

http://dzs.ffzg.unizg.hr/text/pog4.htm (visited on $23^{\text {th }}$ August 2019).

https://www.etno-muzej.si/sl/lokacije/knjiznica (visited on $26^{\text {th }}$ August 2019). 